\title{
Human Assets Administration Practices \& Job Satisfaction: A Obtain Competencies of Hotel Industry
}

\author{
Dr. Rajeev Singh \\ Principal, AVS Presidency International College, Raipur
}

\begin{abstract}
This gain knowledge of ambitions at exploring the influence of Human useful resource administration (HRM) practices on job satisfaction (JS) within the context of lodge manufacturer. JS approach feel of inside fulfillment \& pride performed when performing a exact job. The population of be proficient quilt the chosen employees of hotels \& the sample dimension of 88 employees had been chosen, utilizing the straightforward random sample systems. The survey instrument used within the collection of information was as soon as the questionnaire. This gain knowledge of is restricted to only 5 lodgings of Jabalpur division. It was determined that HRM practices have colossal group with JS. Furthermore, recruitment \& choice, working \& service growth had been determined to have confident have an effect on JS. The hypotheses had been demonstrated, \& respectable result was once completed i.e. Have an affect on of HRM practices on job satisfaction. In this be educated, some statistical measures related to Z-scan, suggest \& share analysis is used to compare employee's satisfaction. Conclusion \& Ideas had been recounted \& bounds of the gain knowledge of are released
\end{abstract}

Keywords: phrases: HRM Practices; hotel industry; Job satisfaction; Jabalpur, MP

\section{Introduction}

A lot of researchers have observed that HRM Practices are positively linked with worker job pride (Wright et al., 2003; Spector, 1997); Petrescu \& Simmons, 2008). But surprisingly, very confined number of reviews have been conducted on HRM practices in the context of establishing international locations ordinarily (Sing, 2004, Yeganeh \& Su, 2008, Mahmood, 2004). This gain knowledge of has been carried out to fill the existing research hole \& to explore the connection between HRM practices \& job satisfaction within the context of motels of Jabalpur division. Academicians, researchers, coverage-makers, practitioners, scholars, local \& overseas entrepreneurs India $\&$ different setting up international locations could advantage from this be taught by means of exploring the association between HRM practices \& job satisfaction. Increasing international competitors have created colossal challenges on organizations. To manage with the challenges efficiently, Human useful resource has been considered as one of the most main motives in in these days"s hyper-aggressive market position. In the context of a developing economic climate like India, where the need for formation of capital is urgent, the place traits in the subject of commercial \& bank management are dynamic, \& the place economic crises accompanying pangs of fiscal growth are widespread, the challenges posed with the aid of HRM are high-quality value; \&, as a sequel, exploring the prospects of the appliance of HRM turns into a very vital discipline of enquiry \& research. Human resource is probably the most priceless asset $\&$ tender aspect of construction. On this global competitive world, it is critical to keep expert workers in the institution through effective HRM practices. Every institution operates its events with the help of HRM which includes top level managers, executives, supervisors \& other workers. The total performance of any institution is dependent upon the extent to which human resource is with ease utilized. This study assesses the influence of Human useful resource administration practices (recruitment \& selection, service progress \& working situation) on job satisfaction in hotel enterprise. The determination of hotel industry for this be trained is completed deliberately due to the fact that the job pride has direct implication for the success of this sector. This paper starts off evolved with brief overview on the imperative literature on HRM, job pride, relation of HRM practices \& job satisfaction. Then hypotheses of exclusive dimensions of HRM practices \& their influence had been validated in order that it can be empirically examined the have an effect on with job pride. The paper then discusses the discovering of the study \& draws the conclusions established on the empirical evaluation of the be taught.

\section{Objective to be trained}

The target of the gain knowledge of was to identification the have an effect on of various dimensions of Human useful resource administration (recruitment \& resolution, provider development, working ) on job pride.

\section{Literature Review}

Human useful resource administration Practices

Human useful resource management (HRM) refers to the policies \& practices involved in conducting the „human useful resource $(\mathrm{HR})^{\text {ec }}$ elements of a management position together with human resource planning, job analysis, recruitment, selection, orientation, compensation, efficiency appraisal, training \& progress, \& labour relations (Dessler, 2007). The Human useful resource management (HRM) movements can be summarised in short below five main domains: (i) organizational design; (ii) staffing; (iii) efficiency management appraisal; (iv)employment coaching \& institution development; \& (v) reward techniques, advantages \& compliance (Beardwell, et 


\section{International Journal of Science and Research (IJSR) \\ ISSN (Online): 2319-7064}

Index Copernicus Value (2013): 6.14 | Impact Factor (2015): 6.391

al., 2004). The overall intent of human resource management is to make certain that the group is competent to achieve success via men \& women (Armstrong, 2006). However, as acquired in the literature, HRM is stated to be worried with attaining the following: organizational effectiveness; human capital management; competencies administration; reward management; employee family members \& meeting various wants (Armstrong, 2006). HRM consists of the insurance policies, practices, \& systems that impact workers ${ }^{\text {ce }}$ conduct, attitude, \& performance (Noe, Hollenbeck, Gerhart, \& Wright, 2007).

\section{Job Satisfaction}

Job satisfaction is a combo of cognitive \& affective reactions to the differential perceptions of what an employee wants to obtain compared to what he or she actually receives (Boyt, Lusch, \& Naylor, 2001). Job pride is a state where one ees $^{\text {s }}$ desires \& one ${ }^{\text {ee }}$ effects match well (Locke, 1976). It has been argued that employees frequently respect rewards on one h\& at the same time on the opposite h\& repugnant effort. Virtually, there is must see employment demands beyond the exchange of services for salaries. Though, employment needs is noticeable as economic relation in nature, but it is most important to notice that it has a strong affiliation to social \& psychological views (Baron \& Kreps, 1999). Essentially the most referred definition of job pride was provided through Locke (1976) who outlined job satisfaction as a wonderful or confident emotional state attributable to the evaluation of a

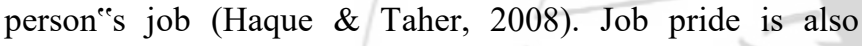
outlined as an man or woman ${ }^{\text {ee }}$ common attitude involving his or her job (Robbins, 1999). Job satisfaction has a large impact on workerse ${ }^{\text {ee }}$ organizational dedication, turnover, absenteeism, tardiness, accidents, \& grievances (Byars \& Rue, 1997; Moorhead \& Griffin, 1999). Job satisfaction method what are the feelings of extraordinary workers in regards to the unique dimensions of their jobs (Robbins, 2003). The extent of pride \& dissatisfaction is a further facet which is concerning employee job satisfaction (Spector, 1997). Job satisfaction is also the overall conduct emerged as a result of extraordinary happenings on the work position; it will be supervisors behavior, relationship with peers or the work environment (Janet, 1987).

\section{HRM Practices \& Job satisfaction}

HRM practices \& job satisfaction are studied commonly in exclusive components of the arena. It's assumed that HRM practices are intently associated with job satisfaction (Ting, 1997). Considering many scholars \& practitioners consider that sound HRM practices influence in higher stage of job satisfation which eventually improves organizational performance. Steijn (2004) located that HRM practices had positive effect on job pride of the workers of Dutch public sector whereas character traits such as age, gender, \& education had insignificant outcomes on job satisfaction. Gould-William (2003) showed that use of exact HR practices in regional govt corporations in the United Kingdom (UK) used to be associated with a larger degree of job satisfaction, office believe, dedication, effort, \& perceived organizational performance.

\section{Hypothesis}

Hypothesis 1: have an effect on of "Recruitment \& resolution" on job satisfaction.

The recruitment \& resolution system determines the choices as to which candidates will get employment presents. The goal of this practice is to support the fit between employees \& the organization, teams, \& work specifications, \& for that reason, to create a greater work environment (Tzafrir,2006). Refined recruitment \& determination process can be certain a better match between the person es talents \& the group "s requirement (Fern\&ez, 1992). Hunter \& Schmidt (1982) concluded that employment steadiness could be done through a decision approach situated on capacity. Katou \& Budhwar (2007) in a gain knowledge of on the Greek manufacturing businesses determined that recruitment \& choice was once positively associated to all organizational efficiency variables such as effectiveness, efficiency, innovation, \& best.

Hypothesis 2: influence of "carrier development" on job satisfaction.

Provider progress also influences different HRM practices such as recruitment \& determination, working. The promoted workers feel valued by means of the institution, \& realize that the institution is inclined to invest in them in the long run (Pfeffer 1995). Miller \& Wheeler (1992) observed that the lack of meaningful work \& opportunities for merchandising significantly affected staff intentions to depart an group. Corporations had been ready to give a boost to their employees' retention cost through adopting job enrichment packages \& adorning their development possibilities.

Besides advertising opportunities, the evaluation standards used within the merchandising \& reward procedure also had significant effects on workers ${ }^{\text {ee }}$ turnover intentions (Quarles, 1994). Interior promotion; the availability of career potentialities inside the firm tends to advertise a better degree of organizational dedication amongst staff (guest, 1997) who understand career potentialities with the firm. Moreover, an emphasis on inner merchandising is likely to furnish a sense of fairness \& justice among the workers who notice that organizational tenure is valued within the corporation (Pfeffer, 1995).

\section{Speculation three: impact of "Working situation" on job satisfaction}

Working conditions is working environment provided by using the corporation/institution \& in addition identified to be the non-pay points of stipulations of employment, which include the following; amenities, measure of protection, wellness, well-being, \& so on., (Bockerman \& Ilmakunnas, 2006). Working conditions is the stipulations in which worker works \& routine akin to training; working time, workexistence stability, etc., (Majid, 2001). Nearly, there's a particular change between staff \& jobs. Employers may just pick to provide exceptional working stipulations for different staff regarding the variety of employment supplied; contract or everlasting. Nevertheless, the study shall take one of the 


\section{International Journal of Science and Research (IJSR) \\ ISSN (Online): 2319-7064}

Index Copernicus Value (2013): 6.14 | Impact Factor (2015): 6.391

components into consideration comparable to defense at work, flexible arrangement, time beyond regulation, with no alternative to any.

Work flexible arrangements have have an effect on on worker household conflict (Kossek et al., 2005). Additional time plays a relevant function (Peters,2000; Robert Reich, 1992). Employees demand more friendly work flexibility (Fleet wood, 2007); they demand employeefriendly flexibility, where they assess how a lot, when \& the place they work, which include voluntary part-time work, flexible working hours, \& so on. Unfavourable working stipulations largely increase the extent of job dissatisfaction (Bockerman \& Ilmakunnas 2006). Therefore, the above evaluate of literature shows that there were a couple of studies all over the world focusing on HRM practices \& job satisfaction. Nevertheless, reports portraying the impact of HRM Practices on job satisfaction in the resort enterprise have no longer yet got correct concentration in India \& different developing countries. This study has been undertaken to fill the prevailing research gap.

\section{Research Methodology}

\section{Knowledge Sources \& Instrumentation}

This paper is centered on both most important \& secondary knowledge. Most important knowledge were accrued through a structured questionnaire which was administered to employees of hotel enterprise. Effortless pattern process has been used to interview the workers. The goal populace of this be taught used to be workers in Jabalpur division who have been serving as a staff in unique lodges in Jabalpur division. For conducting this study, five lodges of Jabalpur division had been chosen $\&$ from these five hotels total a hundred inn workers were chosen $\&$ out of this only 88 workers responses appropriately, the response fee is 88 percent. The questionnaire includes specific questions about three HRM dimensions reminiscent of recruitment \& selection, provider progress, working stipulations. A 5 aspects ranking scales of questionnaire from strongly disagree (1) to strongly agree (5) had been adopted to measure the variables of HRM Practices. Job satisfaction was once measured through a one-object questionnaire on 5factor Likert scale [where disagree (1) to strongly agree (5)]. The secondary information used within the learn have been accrued from associated journals, books, newspaper \& web, \& many others.

\section{Knowledge analysis \& findings}

in the present be taught, knowledge is analyzed through enter wise process in a multiple regression analysis. On this context, a more than one regression was once carried out, by using making use of all the discrete variables (i.E., elegant \& impartial variables) available within the dataset. In this study, some statistical measures such as Z-scan, mean \& proportion analysis is used to compare job pride.

Hypothesis to be established:

H1: there's no have an effect on of "Recruitment \& selection" on job pride; it is assumed from the hypothesis that recruitment $\&$ choice has enormous have an effect on on job satisfaction. Desk 1 shows that at zero.05 stage of significance (two tailed experiment), table worth (1.96) is better than calculated worth $(\mathrm{Z}=$ zero.55). So, the null hypothesis is accepted $\&$ for this reason, we conclude that "Recruitment \& determination" have gigantic affect on job satisfaction.

Table 1: Computation of $Z$ value

\begin{tabular}{|c|c|c|c|c|c|}
\hline Particulars & Variables & N Mean & St\&ard Mean & Z Value & Rank \\
\hline R \& S & 90 & 3.06 & .11 & .55 & 1 \\
\hline CG & 90 & 2.54 & .11 & 4.18 & 6 \\
\hline WC & 90 & 3.02 & .12 & .17 & 3 \\
\hline
\end{tabular}

Source: Survey data

\section{H2: There is no influence of "Carrier Growth" on job satisfaction;}

This hypothesis indicates that there is no influence of carrier growth on job satisfaction. Table 1 shows that at 0.05 level of significance (two tailed test), table value (1.96) is less than calculated value $(Z=4.18)$. So, the null hypothesis is rejected $\&$ hence, we conclude that there is no influence of "Carrier Growth" on job satisfaction.

\section{H3: There is no influence of "Working condition" on job satisfaction;}

This hypothesis indicates that there is great influence of working condition on job satisfaction. Table 1 shows that at 0.05 level of significance (two tailed test), table value (1.96) is greater than calculated value $(Z=0.17)$. So, the null hypothesis is accepted $\&$ hence, we conclude that there is great influence of "Working condition" on job satisfaction. From the above hypotheses testing it shows that there is great influence of HRM practices on job satisfaction on some dimensions such as recruitment \& selection (mean rank01) \& working condition (mean rank-03).The hypotheses test also shows that there is no influence on career growth (mean rank-02). Therefore, it is clear that all dimensions are not equally satisfied. It is also very clear from the Table 2 which dimensions highly satisfied or dissatisfied percentage of satisfaction.

Table 2: Percentage of Satisfaction

\begin{tabular}{|c|c|c|c|c|c|c|}
\hline Particuler & Dissatisfied. & $\begin{array}{c}\text { Some How } \\
\text { Satisfie }\end{array}$ & Satisfied & Moderately Satisfi & Highly Satisfie & Total \\
\hline .RNS & 7.95 & 17.05 & 43.18 & 25 & 6.82 & 100 \\
\hline CG & 11.36 & 43.18 & 29.55 & 11.36 & 4.55 & 100 \\
\hline WC & 9.09 & 22.73 & 36.36 & 20.45 & 11.36 & 100 \\
\hline
\end{tabular}

Note: RNS1 = Recruitment \& Selection, CG2= Career Growth, WC3= Working Condition 


\section{International Journal of Science and Research (IJSR) \\ ISSN (Online): 2319-7064}

Index Copernicus Value (2013): 6.14 | Impact Factor (2015): 6.391

Table 2 shows percentage of different levels of Satisfaction. The table indicates that the highest 43.18 percent of respondents are satisfied that recruitment \& selection have great influence on job satisfaction followed by 36.36 percent on working condition $\&$ the lowest 29.55 percent on carrier growth. Table 2 also shows that the highest 11.36 percent respondents are highly satisfied on working condition $\&$ the lowest 4.55 percent on carrier growth. The study also indicates that the highest 11.36 percent of respondents are dissatisfied on carrier growth, 9.09 per cent on working condition \& the lowest 7.95 per cent on recruitment \& selection. Therefore, the analysis shows that there is no complete job satisfaction on any HRM dimensions of hotels. So, the HRM dimensions quality of hotels should be improved for the success of the hotel industry.

\section{Conclusions \& Recommendations}

The study disclosed the impact of various dimensions of HRM practices on job satisfaction. In this study, we considered three major factors which represented most of the HRM practices followed by different hotels. The study reveals that all HRM dimensions exercised in the hotels of Jabalpur division does not satisfied to the employees equally. Employees are satisfied with recruitment \& selection \& working condition \& dissatisfied with carrier growth. It is obvious that HRM practices in the hotel industry of Jabalpur division has not been fully developed \& there is the urgent need to employ the services of HRM professionals, consultants \& researchers to help shape \& develop new directional focus that will ensure an efficient \& effective human resource practices. We suggest the following recommendations for doing perfect HRM practices in the hotel industry of Jabalpur division.

1)Proper working environment should be designed

2)Organizations should implement proper recruitment \& selection process.

3)Mangt. should make a clear cut career advancement path.

4) Organizations should provide unbiased promotion.

5)That is promotion should be provided based on the qualification of employees \& /or experience.

6)Organization should design working procedure including hours work. Proper working environment should be designed.

\section{Limitations}

- Only five hotels of Jabalpur division were selected. Small sample size was one of the major limitations of the present study. The study did not cover all the HRM practices of the surveyed Hotel industry.

\section{Suggestions for Future Research}

- Several suggestions that fruitful for future research emerged from this present study. In order to validate the findings of this study, case study is another interesting approach that can be done by future research.

\section{References}

[1] Bockerman P. \& Ilmakunnas P.(2006), Do Job Disamenities Raise Wage or Ruin Job Satisfaction, International Journal of Manpower 27(3): 290-302.

[2] Katou, A. A., Budwar, P. S., The effects of human resource management policies on organizational performance in Greek manufacturing firms. Thunderbird International Business Review, 49(1), pp.1-35, 2007.

[3] Dessler, G., Human resource management. New Delhi: Prentice Hall of India Private Limited 2007.

[4] Locke, E.A. (1976), "The nature \& causes of job satisfaction", in Dunnette, M.C.(Ed.), Handbook of Industrial \& Organizational Psychology, Sage, Beverly Hills, CA, pp. 1(297-349).

[5] Majid, Nomaan (2001),.The Working Poor in Developing Countries., International Labour Review, 140(3): 271-91.

[6] Petrescu, A. I., Simmons, R., Human resource mangtt practices \& workerse job satisfaction.Int. Journal of Manpower, Vol.29, No.7, pp. 651-667, 2008.

[7] Pfeffer, J. (1995),Producing Sustainable Competitive Advantage through the Effective Mangt People ${ }^{\text {ee }}$, Academy of Management Executive, Vol.9, pp.55.

[8] Ting, Y., Determinants of job satisfaction of federal government employees, Public Personnel Mangt,Vol 26 No.3, pp. 313-334, 97.

[9] Yeganeh, H., Su, Z., An Examination of human resource management practices in Iranian public sector. Personnel Review, Vol. 37, No.2, pp. 203-221, 2008.

[10] Singh, K., Impact of HR practices on perceived firm performance in India. Asia Pacific Journal of Human Resources, Vol.42, No.3, pp. 301-317, 2004.

\section{Author Profile}

Prof. Rajeev Singh has published many research papers \& articles in International \& National peer reviewed journals. He also published research reference books too. He is member of IAAO, ICMA, MPCMA, MPEA, AIMA.. His specialization is on Entrepreneurship Development. He had organizes many research base programmes like workshops conferences and seminars 